\title{
Evaluation of Six Patients with Chromosome 18 Structural Anomalies and Novel Findings
}

\author{
(1) Esra Işık, (1) Bilcağ Akgün, (1) Tahir Atik, (1) Ferda Özkınay, (D) Özgür Çoğulu \\ Ege University Faculty of Medicine, Department of Pediatrics, Division of Pediatric Genetics, İzmir, Turkey
}

\section{ABSTRACT}

Aim: Structural chromosome 18 anomalies are characterized by multiple congenital anomalies and intellectual disability. In this study, 6 cases with structural anomalies of chromosome 18 diagnosed by using conventional and molecular cytogenetic analyses are presented.

Materials and Methods: Six cases who were carrying structural chromosome 18 abnormalities were enrolled in the study. Developmental milestones, growth parameters and dysmorphologic features were evaluated by experienced clinical geneticists. Laboratory analysis including genetic tests, imaging studies, and eye and hearing examinations were obtained from the medical records, retrospectively.

Results: All cases had karyotype analysis, 2 cases had fluorescence in situ hybridization analysis and one case had microarray analysis, which were performed by using peripheral blood. A total of 6 cases in which del (18p) in one case, del (18q) in 4 cases and $i(18 q)$ in one case were evaluated.

Conclusion: Although a wide range of phenotypic findings, depending on the affected chromosomal region and size, can be seen in patients who carry structural chromosome 18 anomalies, some additional novel features are presented in our series which will contribute to the literature.

Keywords: Chromosome 18, structural anomalies, deletion, duplication, isochromosome

\section{Introduction}

The most common structural chromosome 18 anomalies are deletions of both the $\mathrm{p}$ and $\mathrm{q}$ arms, ring chromosome, isochromosome and inversions. The first three anomalies occur in approximately 1 in 40,000 live births (1). Clinical findings of all these anomalies vary depending on the genes found in the affected region.

Although deletions on the proximal part of the $\mathrm{q}$ arm of chromosome 18 show a wide range of clinical pictures, they all fall under the term "18q Deletion syndrome" (2). This is similar for "18p Deletion syndrome" as well. However, cases with ring chromosome 18 and isochromosome 18q present with more specific features (3). Here, we report the findings of 6 cases with deletions of the $p$ and $q$ arms of chromosome 18, and isochromosome of the $q$ arm of chromosome 18.

In this study, 6 cases with structural anomalies of chromosome 18 diagnosed by using conventional and molecular cytogenetic analyses are presented.

\section{Materials and Methods}

Six cases who were carrying structural chromosome 18 abnormalities were enrolled in the study. These cases were collected from the archive of the Ege University Faculty of Deparment of Pediatric Genetics. These cases and their files were evaluated by experienced clinical 
geneticists. Dysmorphologic features, growth parameters and developmental milestones were noted. Laboratory tests, imaging studies, and eye and hearing examinations were obtained from the medical records, retrospectively. All cases had karyotype analysis, 2 cases had fluorescence in situ hybridization analysis and one case had microarray analysis, which were performed by using peripheral blood. Descriptions of these cases are as follows.

The study was approved by the Ethical Committee of the Ege University Medical Faculty (approval number: 20-3T/28, date: 04.03.2020). Written informed consent was obtained from all the patients or their parents/guardians.

\section{Statistical Analysis}

Descriptive analysis was used to evaluate the data in the study.

\section{Results}

\section{Case 1}

A 2-year-old girl was referred because of developmental delay (Figure 1a). She was born to non-consanguineous healthy parents at the $38^{\text {th }}$ week of gestation by cesarean section. Her birth weight was $2,800 \mathrm{~g}$ and birth length was $50 \mathrm{~cm}$.

On physical examination, her weight, length, and occipitofrontal circum ference (OFC) were $10,600 \mathrm{~g}\left(25-50^{\text {th }}\right.$ centile), $77 \mathrm{~cm}$ (3-10 ${ }^{\text {th }}$ centile), and $44 \mathrm{~cm}$ (25-50 th centile), respectively. Hypertrichosis, round face, short neck, low hair line, flared eyebrows, hypertelorism, broad nasal bridge, prominent columella, high palate and teeth abnormalities were observed. She had also X-bain deformity and pes equinovarus. Severe developmental delay was detected using the Ankara Developmental Screening Inventory. A cranial magnetic resonance image (MRI) revealed thin corpus callosum, cortical atrophy and ventricular dilatation. Her laboratory tests, abdominal ultrasonography, echocardiography, skeletal survey, and eye and hearing examinations were all normal. The peripheral leukocyte karyotype was 46,XX,del(18)(p11.2) and subtelomeric FISH confirmed 18p deletion (Figure 1b).

\section{Case 2}

The patient was a 6-month-old girl born at the $40^{\text {th }}$ week of gestation by normal spontaneous vaginal delivery with a birth weight of 2,200 g. She was the second child of healthy non-consanguineous parents. She was hospitalized for lower respiratory tract infection at the second month of age and, at that time, a secundum atrial septal defect (ASD) was detected using echocardiography.
On physical examination, her weight, length, and OFC were $4,500 \mathrm{~g}\left(10^{\text {th }}\right.$ centile), $58 \mathrm{~cm}\left(3-10^{\text {th }}\right.$ centile), and 35.7 $\mathrm{cm}\left(<3^{\text {rd }}\right.$ centile), respectively. On neurological examination, generalized hypotonia and spasticity in the lower extremities were noted. Deep tendon reflexes were found to be decreased. Her developmental milestones were delayed. Additional dysmorphic features included brachycephaly, midface hypoplasia, hypertelorism, depressed and wide nasal bridge, low set ears, long philtrum, micrognatia and overlapping toes. The patient's eye contact was decreased and an eye examination showed posterior embryotoxon. Atrophy of corpus callosum was detected on cranial MRI. Standard karyotype analysis revealed 46,XX,del(18)(q21.1) (Figure 2). Her picture was not available.

\section{Case 3}

A 2 and half-year-old girl was born to consanguineous healthy parents at the $35^{\text {th }}$ week of gestation by cesarean section due to oligohydramnios (Figure 3). Her birth weight was $2,470 \mathrm{~g}\left(50^{\text {th }}\right.$ centile) and her birth length was $49 \mathrm{~cm}$ (75-90 ${ }^{\text {th }}$ centile).

On physical examination, her weight, length, and OFC were $8,600 \mathrm{~g}\left(3-10^{\text {th }}\right.$ centile), $75 \mathrm{~cm}\left(10^{\text {th }}\right.$ centile $)$, and $41 \mathrm{~cm}$

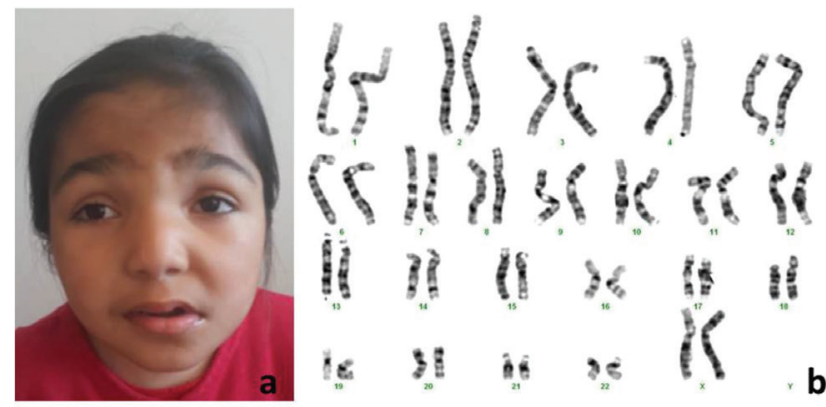

Figure $\mathbf{1 a}$ and $\mathbf{1 b}$. Facial appearance of case 1 and karyotype analysis

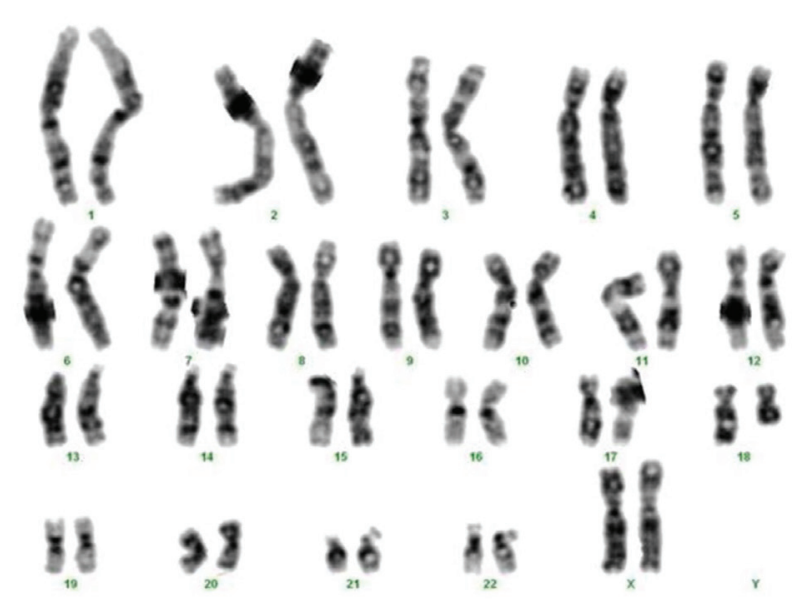

Figure 2. Karyotype analysis of case 2 
$\left(<3^{\text {rd }}\right.$ centile), respectively. Microcephaly and dysmorphic facial features such as hypertelorism, epicanthus, low set and posterior rotated ears, depressed nasal bridge, anteverted nares and thin upper limb were noted. She also had tapered fingers, finger pads, unilateral simian line, rocker bottom feet and lymphedema on bilateral hands and feet. Eye examination showed bilateral chorioretinal atrophy and a cranial MRI revealed delayed myelination on the cerebral white matter. The peripheral leukocyte karyotype was 46,XX,del(18)(q21.3).

\section{Case 4}

A2andhalf-year-oldboywasborntonon-consanguineous healthy parents at the $40^{\text {th }}$ week of gestation by cesarean section. His birth weight was $3,500 \mathrm{~g}\left(25-50^{\text {th }}\right.$ centile) and his birth length was $51 \mathrm{~cm}\left(25-50^{\text {th }}\right.$ centile).

On physical examination, his weight, length, and OFC were $14 \mathrm{~kg}$ (25-50 ${ }^{\text {th }}$ centile), $94 \mathrm{~cm}$ (50-75 th centile), and 49 $\mathrm{cm}\left(50^{\text {th }}\right.$ centile), respectively. Coarse face, broad forehead, facial hemangioma, hypertelorism, upslanting palpebral fissures, depressed nasal bridge and micrognathia were noted (Figure 4a). He also had proximal placement of the thumb, long thin fingers and overriding toes. His laboratory tests, abdominal ultrasonography, echocardiography, skeletal survey, and hearing examination were all normal. Eye examination showed infantile nystagmus and hypermetropia and a cranial MRI revealed hypomyelination on the cerebral

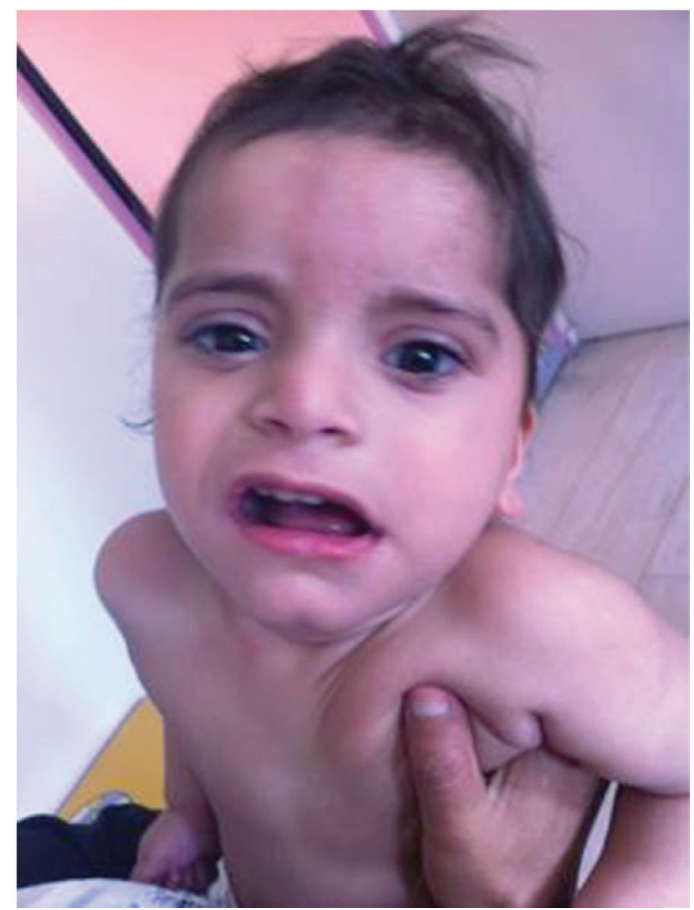

Figure 3. Facial appearance of case 3 white matter and thin corpus callosum. The peripheral leukocyte karyotype was 46,XY (Figure 4b). Subtelomeric $\mathrm{FISH}$ analysis revealed subtelomeric deletion on the long arm of chromosome 18.

\section{Case 5}

A 7-year-old-girl was referred due to her dysmorphic facial features. She was born at the $38^{\text {th }}$ week of gestation. Her birth weight was 2,750 g (10-25 th centile) and her birth length was $50 \mathrm{~cm}$ (50-75 th centile).

On physical examination, her weight, length, and OFC were $16.8 \mathrm{~kg}$ ( $<3^{\text {rd }}$ centile), $116 \mathrm{~cm}\left(3-10^{\text {th }}\right.$ centile), and $49 \mathrm{~cm}$ (3-10 ${ }^{\text {th }}$ centile), respectively. Thin upper lip, large mouth, high-arched palate and 2-3 syndactyly of the toe were observed. Her laboratory tests, cranial MRI, abdominal ultrasonography, skeletal survey, hearing examination and eye examination were all normal. Echocardiography revealed mild mitral-tricuspid insufficiency and pulmonary stenosis. The peripheral leukocyte karyotype was 46,XX,del(18)(q22.1) (Figure 5). DNA microarray analysis revealed a $13 \mathrm{MB}$ deletion at 18q22.1-q23 location which contains 27 online mendelian inheritance of man (OMIM) genes and $12 \mathrm{MB}$ duplication at 11q24.1-q25 location which contains 54 OMIM genes.

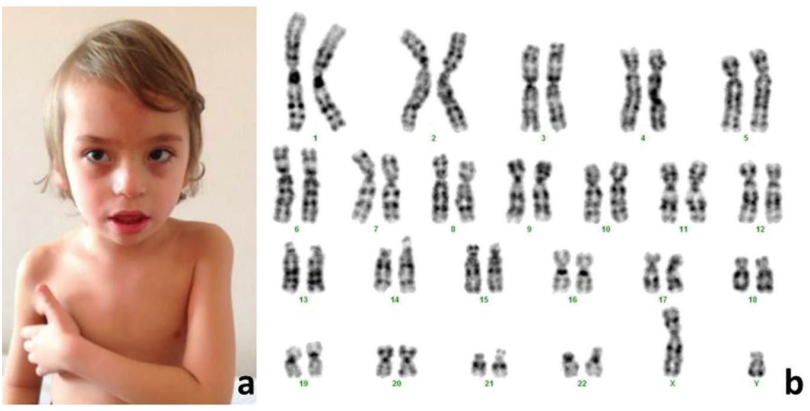

Figure $\mathbf{4 a}$ and $\mathbf{4 b}$. Facial appearance of case 4 and karyotype analysis

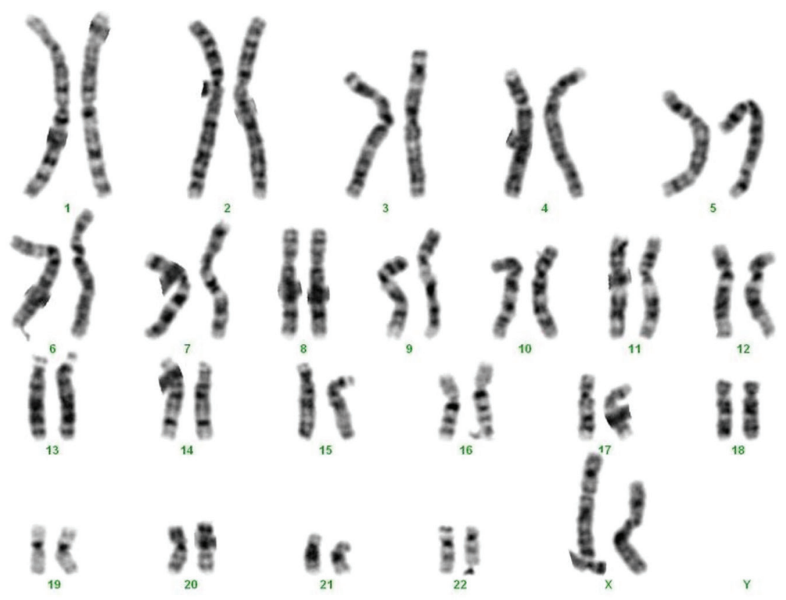

Figure 5. Karyotype analysis of case 5 


\section{Case 6}

A 6-month-old girl was born to non-consanguineous healthy parents at the $36^{\text {th }}$ week of gestation by cesarean section. Her birth weight was 2,200 g (10-25 th centile) and her birth length was $45 \mathrm{~cm}$ (10-25 ${ }^{\text {th }}$ centile). Following birth, she was admitted to hospital due to respiratory insufficiency and followed in the neonatal intensive care unit for 15 days. After discharge from hospital, she suffered from recurrent respiratory system infections.

On physical examination, her weight, length, and OFC were $4,800 \mathrm{~g}$ ( $<3^{\text {rd }}$ centile), $53 \mathrm{~cm}\left(<3^{\text {rd }}\right.$ centile) and $38 \mathrm{~cm}$ $\left(25^{\text {th }}\right.$ centile), respectively. Short stature, exophthalmos, ptosis, blue sclera, low set ears, long philtrum, high arched palate, and micrognathia were noted. She also had pectus excavatum, fusiform fingers, hallux valgus and pes equinovarus. Her laboratory tests and abdominal ultrasonography were normal. She had sensorineural hearing loss and auditory evoked potentials detected high hearing levels, $60 \mathrm{~dB}$ on the right ear and $75 \mathrm{~dB}$ on the left ear. Eye examination was normal, however visual evoked potential revealed bilateral partial conduction defects. Coxa valga and bilateral delayed ossification of the proximal capital femoral epiphysis were detected on skeletal survey. Echocardiography showed a $2 \mathrm{~mm}$ ventricular septal defect, and a cranial MRI revealed thin corpus callosum. The peripheral leukocyte karyotype was 46,XX,i(18)(q10) (Figure $6)$. The clinical features and molecular findings of the all patients were given in Table I. Written informed consent was obtained from all the patients or their parents/guardians.

\section{Discussion}

Chromosome 18 is one of three chromosomes in which trisomic individuals survive to term. It has the lowest gene

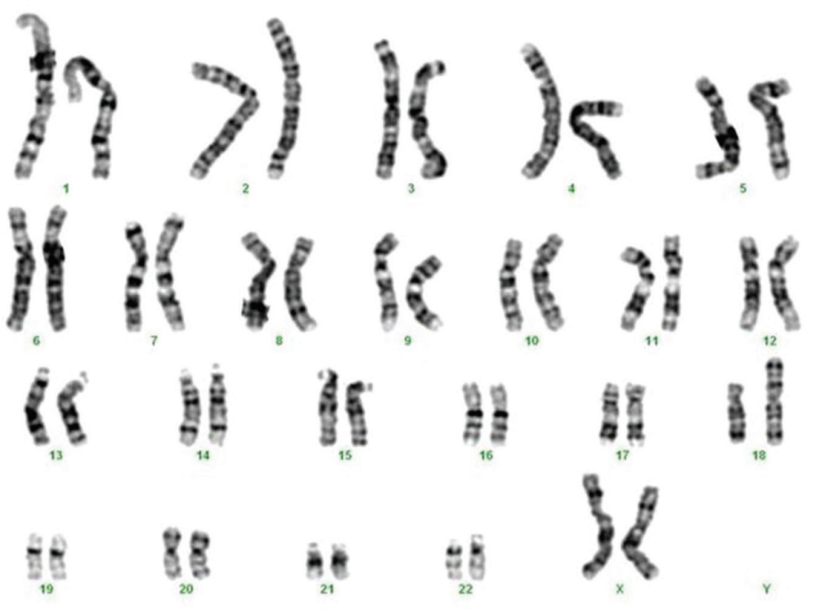

Figure 6. Karyotype analysis of case 6 density among all chromosomes. Trisomy of chromosome 18, Edwards syndrome, is the second most common autosomal trisomy following Down syndrome, and is characterized by growth retardation and severe congenital abnormalities such as holoprosencephaly and congenital heart defects (4). To date, besides trisomy 18, many cases with structural abnormalities of chromosome 18 such as deletion and duplication, inversion, isochromosome and ring chromosome have been reported in the literature. In this study, we present 6 cases with chromosome structural anomalies in which one had $p$ arm deletion, 4 had $q$ arm deletion and one had isochromosome.

Chromosome 18p deletion was first described in 1963 by de Grouchy (3). It is one of the most frequent autosomal abnormalities. The incidence of the deletion 18p syndrome can be estimated to be about 1:50,000 live born infants. About 2/3 of cases with this anomaly are de novo deletions. Similar to the information in the literature, chromosomal anomaly in our case occurred de novo. The breakpoint in this syndrome clusters at 18p11.1. Although the phenotype is highly variable, the clinical picture is mostly very moderate. It is mainly characterized by intellectual disability, short stature, facial dysmorphism including round face with short philtrum, palpebral ptosis and large ears with detached pinnae, hearing impairment, and genitalia and foot deformities $(5,6)$. As is described in the literature, round face was typical in our case. Unusual phenotypic findings such as hypertrichosis and pes equinovarus were present besides the main clinical findings reported in this syndrome. The breakpoint of the deletion on chromosome 18p in our case seems to be in 11.2 band. The region between 11.21 and 11.1 has been suggested to be a critical region for intellectual disability by Wester et al. (7). Developmental delay in our case also supports this suggestion.

Long arm deletion of chromosome 18 may occur in different regions of the long arm of chromosome 18 (2). In our series, 4 children were found to have long arm deletions. Three of them were carrying the most common breakpoints for chromosome 18 which is described as 18q Deletion syndrome. The breakpoints in this syndrome may start from $18 q 21.1,18 q 21.3$ or $18 q 22.2$ extending to 18qter. Although the phenotype is highly variable, some characteristic findings are intellectual disability, short stature, hypotonia, hearing impairment, and foot deformities. At the same time, cardiac and immunologic features may also be observed in these cases (8). Embryotoxon and facial hemangioma were additional findings in our case 3 and case 4, which have not been previously reported in the literature. Delayed myelination and tapering digits as presented in these 2 
cases may also be taken into consideration in the diagnostic approach to $18 q$ deletion syndrome. The $18 q 22.3$ region has been reported as the critical region for palate abnormality (9). Case 5 had a high arched palate and showed a deletion between q22.1 and q23 which comprises this critical region. Seizures can also be seen in both the deletion syndromes of chromosome $18 \mathrm{p}$ and $\mathrm{q}$ arms (10), however none of our patients with these deletions had a history of seizures.

Case 5 was found to be carrying a duplication at 11q24.1-q25 location in addition to 18q22.1-q23 deletion. 11q24.1-q25 duplication is a rare cytogenetic anomaly. It has been described in a 15-year-old male with ASD (11). His father and affected twin sister were found to have the same duplication. No symptom of ASD was observed in our patient.

Isochromosome $18 \mathrm{q}$ is another rare chromosome 18 structural abnormality. The incidence is reported to be 1 in 8,000 . The clinical findings of iso(18q) resemble Edwards syndrome. Intellectual disability, marked growth deficiency, typical facial anomalies such as prominent occiput, faun-like ears, micrognathia, cardiac anomalies, and skeletal findings are the characteristic features of iso(18q). Holoprosencephaly, cebocephaly and cyclopia as distinctive features and microcephaly, hypotelorism and hypoplastic nose as unique findings have been reported in iso(18q) $(12,13)$. However, apart from thin corpus callosum,

Table I. Phenotypic features and cytogenetic analysis results of the case

\begin{tabular}{|c|c|c|c|c|c|c|}
\hline & Case 1 & Case 2 & Case 3 & Case 4 & Case 5 & Case 6 \\
\hline $\begin{array}{l}\text { Chromosomal } \\
\text { abnormality }\end{array}$ & $\operatorname{del}(18)(p 11.2)$ & $\operatorname{del}(18)(q 21.1)$ & $\operatorname{del}(18)(q 21.3)$ & $\begin{array}{l}\text { Subtelomeric } \\
\text { del(18q) }\end{array}$ & $\begin{array}{l}\operatorname{del}(18) \\
(q 22.1-q 23)\end{array}$ & $\mathrm{i}(18)(\mathrm{q} 10)$ \\
\hline Cranial MRI & $\begin{array}{l}\text { Thin corpus } \\
\text { callosum, } \\
\text { cortical atrophy } \\
\text { and ventricular } \\
\text { dilatation }\end{array}$ & $\begin{array}{l}\text { Corpus callosum } \\
\text { atrophy }\end{array}$ & $\begin{array}{l}\text { Delayed myelination } \\
\text { on cerebral white } \\
\text { matter }\end{array}$ & $\begin{array}{l}\text { Hypomyelinization } \\
\text { on cerebral white } \\
\text { matter and thin } \\
\text { corpus callosum }\end{array}$ & Normal & $\begin{array}{l}\text { Thin corpus } \\
\text { callosum }\end{array}$ \\
\hline Head & $\begin{array}{l}\text { Low hair line, } \\
\text { round face, } \\
\text { flared eyebrows, } \\
\text { hypertelorism, } \\
\text { strabismus, } \\
\text { broad nasal } \\
\text { bridge, prominent } \\
\text { columella, teeth } \\
\text { abnormalities, high } \\
\text { palate, short neck }\end{array}$ & $\begin{array}{l}\text { Microcephaly, } \\
\text { brachycephaly, } \\
\text { midface } \\
\text { hypoplasia, } \\
\text { hypertelorism, } \\
\text { embryotoxon, } \\
\text { low set ears, } \\
\text { depresed and } \\
\text { wide nasal bridge, } \\
\text { long philtrum, } \\
\text { micrognatia }\end{array}$ & $\begin{array}{l}\text { Microcephaly, } \\
\text { epicanthus, } \\
\text { hypertelorism, } \\
\text { bilaterally } \\
\text { chorioretinal } \\
\text { atrophy, low set and } \\
\text { posterior rotated } \\
\text { ears, depressed } \\
\text { nasal bridge, } \\
\text { anteverted nares, } \\
\text { thin upper limb }\end{array}$ & $\begin{array}{l}\text { Broad forehead } \\
\text { coarse face, fascial } \\
\text { hemangioma, } \\
\text { upslanding } \\
\text { palpebral fissures, } \\
\text { hypertelorism, } \\
\text { nistagmus, } \\
\text { hypermetropia, } \\
\text { depressed } \\
\text { nasal bridge, } \\
\text { micrognathia }\end{array}$ & $\begin{array}{l}\text { Large } \\
\text { mouth, thin } \\
\text { upper lip, high- } \\
\text { arched palate, } \\
\text { peripapillary } \\
\text { atrophy }\end{array}$ & $\begin{array}{l}\text { Exophthalmos, } \\
\text { ptosis, } \\
\text { blue sclera, } \\
\text { low set ears, } \\
\text { sensorineural } \\
\text { hearing loss, } \\
\text { long philtrum, } \\
\text { high arched palate, } \\
\text { micrognathia }\end{array}$ \\
\hline Cardiac & Normal & $\begin{array}{l}\text { Secundum atrial } \\
\text { septal defect }\end{array}$ & $\mathrm{N} / \mathrm{A}$ & Normal & $\begin{array}{l}\text { Mild mitral- } \\
\text { tricuspid } \\
\text { insufficiency } \\
\text { and pulmonary } \\
\text { stenosis }\end{array}$ & $\begin{array}{l}\text { Ventricular septal } \\
\text { defect }\end{array}$ \\
\hline $\begin{array}{l}\text { Growth } \\
\text { and mental } \\
\text { situation }\end{array}$ & $\begin{array}{l}\text { Short stature, } \\
\text { developmental } \\
\text { delay }\end{array}$ & $\begin{array}{l}\text { Intellectual } \\
\text { disability }\end{array}$ & $\begin{array}{l}\text { Developmental } \\
\text { delay }\end{array}$ & $\begin{array}{l}\text { Developmental } \\
\text { delay }\end{array}$ & $\begin{array}{l}\text { Intellectual } \\
\text { disability }\end{array}$ & $\begin{array}{l}\text { Growth } \\
\text { retardation, } \\
\text { intellectual } \\
\text { disability }\end{array}$ \\
\hline Extremity & Pes equinovarus & Overlapping toes & $\begin{array}{l}\text { Tapered fingers, } \\
\text { finger pads, } \\
\text { unilateral simian } \\
\text { line, rocker } \\
\text { bottom feet and } \\
\text { lymphedema on } \\
\text { bilateral hands and } \\
\text { foot }\end{array}$ & $\begin{array}{l}\text { Proximal placement } \\
\text { of thumb, long } \\
\text { thin fingers and } \\
\text { overriding toes }\end{array}$ & $\begin{array}{l}\text { 2-3 syndactyly } \\
\text { of the toe }\end{array}$ & $\begin{array}{l}\text { Fusiform fingers, } \\
\text { coxa valga, } \\
\text { bilateral delayed } \\
\text { ossification of the } \\
\text { proximal capital } \\
\text { femoral epiphysis } \\
\text { hallux valgus and } \\
\text { pes equinovarus }\end{array}$ \\
\hline Other features & $\begin{array}{l}\text { Hypertrichosis, } \\
\text { congenital hip } \\
\text { dislocation }\end{array}$ & $\begin{array}{l}\text { Generalized } \\
\text { hypotonia and } \\
\text { spastisity }\end{array}$ & $\begin{array}{l}\text { Hearing loss, } \\
\text { epilepsy }\end{array}$ & Hypospadias & - & $\begin{array}{l}\text { Recurrent } \\
\text { respiratory system } \\
\text { infections, pectus } \\
\text { excavatum }\end{array}$ \\
\hline
\end{tabular}


none of these were detected in our case. Contrary to this, exophthalmos, ptosis and blue sclera were noted.

\section{Conclusion}

Further case descriptions including the breakpoints of the structural anomalies of chromosome 18 will refine the clinical pictures and pathological mechanisms underlying these phenotypes. In this respect, it is hoped that our case series of chromosome 18 structural anomalies may contribute to the literature.

\section{Ethics}

Ethics Committee Approval: The study was approved by the Ethical Committee of the Ege University Faculty of Medicine (approval number: 20-3T/28, date: 04.03.2020).

Informed Consent: Written informed consent was obtained from all the patients or their parents/guardians.

Peer-review: Enternally peer-reviewed.

\section{Authorship Contributions}

Surgical and Medical Practices: F.Ö., Concept: Ö.Ç., Design: Ö.Ç., Data Collection or Processing: B.A., Analysis or Interpretation: T.A., Literature Search: T.A., F.Ö., Writing: E.I.

Conflict of Interest: None of the authors had conflict of interest.

Financial Disclosure: The authors declared that this study received no financial support.

\section{References}

1. Hsu LYF. Prenatal diagnosis of chromosomal abnormalities through amniocentesis. In: Genetic disorders and the fetus, Milunsky A (Ed), $4^{\text {th }}$ ed. Baltimore, The Johns Hopkins University Press $1998 ; 179$
2. Feenstra I, Vissers LELM, Orsel $M$, et al. Genotype-phenotype mapping of chromosome 18q deletions by high-resolution array $\mathrm{CGH}$ : An update of the phenotypic map. Am J Med Genet Part A 2007; 143:1858-67.

3. de Grouchy J. The 18p-, 18q- and 18r syndromes. Birth Defects $1969 ; 5: 74-87$.

4. Rosa RF, Rosa RC, Zen PR, Graziadio C, Paskulin GA. Trisomy 18: review of the clinical, etiologic, prognostic, and ethical aspects. Rev Paul Pediatr 2013; 31:111-20.

5. Online Mendelian Inheritance in Man, $\mathrm{OMIM}^{\circledR}$. Johns Hopkins University, Baltimore, MD. MIM Number: \{146390\}: \{07/09/2016\}: World Wide Web URL: https://omim.org/

6. Turleau C. Monosomy 18p. Orphanet / Rare Dis 2008; 19;3-4.

7. Wester $\mathrm{U}$, Bondeson ML, Edeby C, Anneren G. Clinical and molecular characterization of individuals with 18p deletion: a genotype-phenotype correlation. Am / Med Genet 2006; 140:1164-71.

8. Chen $\mathrm{CP}$, Kuo YT, Lin SP, et al. Mosaic ring chromosome 18, ring chromosome 18 duplication/deletion and disomy 18: perinatal findings and molecular cytogenetic characterization by fluorescence in situ hybridization and array comparative genomic hybridization. Taiwan J Obstet Gynecol 2010; 49:32732.

9. Dostal A, Nemeckova J, Gaillyova R. The 18q deletion syndrome and analysis of the critical region for orofacial cleft at 18q22.3. I Craniomaxillofac Surg 2009; 37:272-5.

10. Verrotti A, Carelli A, di Genova L, Striano P. Epilepsy and chromosome 18 abnormalities: A review. Seizur 2015; 32:78-83.

11. Maruani A, Huguet G, Beggiato A, et al. 11q24.2-25 MicroRearrangements in Autism Spectrum Disorders: Relation to Brain Structures. Am I Med Genet 2015; 167:3019-30.

12. Park JP, Moeschler JB. Isochromosome 18q revisited. Prenat Diagn 1997; 17:589-90.

13. Pal S, Siti MI, Ankathil R, Zilfalil BA. Two cases of isochromosome 18q syndrome. Singapore Med J 2007; 48:146-50. 